\title{
JURISDICTION AND CHOICE OF LAW ISSUES IN MULTISTATE DEFAMATION ON THE INTERNET
}

\author{
MATTHEW CASTEL
}

The author maintains that the connecting factors for jurisdiction and choice of law in Internet defamation actions brought in Canada should be separately defined to address the problems of libel tourism and predictability of legal consequences.
L'auteur soutient que les facteurs de rattachement applicables à la compétence internationale des tribunaux Canadiens et le droit applicable aux actions en diffamation ne devraient pas être les mêmes afin d'éviter le problème du "tourisme" dans ce domaine du droit et assurer la prévisibilité des conséquences juridiques découlant de propos diffamatoires sur Internet.

\section{TABLE OF CONTENTS}

I. INTRODUCTION . . . . . . . . . . . . . . . . . . . . . . . . . . 153

II. GenERAL CONSIDERATIONS . . . . . . . . . . . . . . . . . . . . . . . 154

A. Substantive LaW of Defamation in Canada $\ldots \ldots \ldots \ldots . \ldots 154$

B. Place of Publication as Place of Tort . . . . . . . . . . . 155

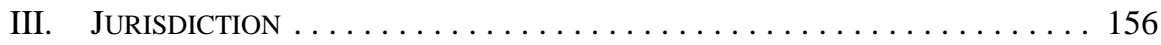

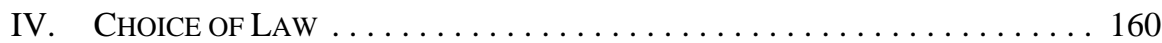

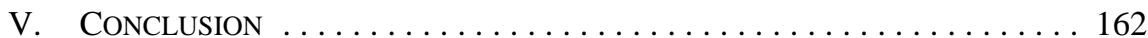

\section{INTRODUCTION}

The Internet age has radically changed the way information travels across borders, but it has also challenged the adequacy of current defamation law principles. ${ }^{1}$ Multistate defamation on the Internet, also called multistate cyber libel, raises a number of important private international law issues due to the fact that publication of a defamatory statement to a third party will generally take place simultaneously in many provinces and states. As a result, the injury to the reputation of the defamed person and the resulting damage may be incurred in several provinces and states. When all the elements of the tort of defamation do not occur in the same province or state, where will the defamed person be able to sue the alleged defamer and under what law? This raises the issue of which court has jurisdiction to hear the action, and then which law the court will apply. ${ }^{2}$ Stephen Pitel and Nicholas Rafferty explain that this issue is difficult to resolve because of the different policy considerations underlying each country's or province's defamation law. ${ }^{3}$ Trevor Hartley goes so far as to say that the harmonization of substantive law is undesirable if not impracticable as the law of defamation reflects the balance a particular society considers just "between two important

BA (Hons) in International Development; LLB and BCL, McGill University; Certificate of International Affairs and Multilateral Governance, Geneva Graduate Institute of International Law and Development Studies. The author is grateful to Professor C Walsh of the McGill Faculty of Law and Distinguished Research Professor Emeritus JG Castel of Osgoode Hall Law School for their useful comments and suggestions.

Aaron Warshaw, "Uncertainty from Abroad: Rome II and the Choice of Law for Defamation Claims" (2006) 32:1 Brook J Int'l L 269 at 269. See also Justice Abella’s description of the Internet's tremendous power to harm reputation in Crookes v Newton, 2011 SCC 47, [2011] 3 SCR 269 at para 37 [Crookes]. Warshaw, ibid at 270 .

Stephen GA Pitel \& Nicholas S Rafferty, Conflict of Laws (Toronto: Irwin Law, 2010) at 266. 
rights: freedom of speech and protection of reputation. This is a delicate cultural matter, and the relative importance of these values differs greatly between different cultures."

In Canada, in all the common law provinces and territories as well as in Quebec, the forum's private international law rules apply. This means that the chosen court must have jurisdiction simpliciter to deal with the action and it must not be forum non conveniens. In this connection, except to some extent in Quebec, the determination of the place of tort plays an important role both with respect to jurisdiction and the applicable law. However, where this place is may be difficult to determine since the scope of freedom of expression may not always be protected in the same way in different jurisdictions. The applicable law will also indicate the type of remedies available to the defamed person, whether it takes the form of general or special damages as well as punitive damages and the removal of the offending material.

This article will consider the place of publication as the place of tort, jurisdiction, and choice of law issues in cases which involve multistate defamation on the Internet. Each of these topics will be examined from a Canadian and comparative law perspective in order to determine whether, at present, there exists a balance between two of the most important policy objectives of private international law: flexibility and predictability of legal consequences as well as between the interests of the plaintiffs in protecting their reputation and the defendants in knowing what standards are to be met. ${ }^{5}$

\section{GENERAL CONSIDERATIONS}

\section{A. Substantive LaW OF DeFamation in CANADA}

In common law Canada, defamation law is largely based on the English common law. ${ }^{6}$ Although the jurisprudence and provincial legislation have evolved in their own unique ways, the essence of the tort of defamation has remained constant. ${ }^{7}$ David Potts explains that "a defamatory statement is one which has a tendency to injure the reputation of the person to whom it refers." ${ }^{8}$ Potts goes on to explain that

[t]o show defamation, the onus is on the plaintiff to prove three elements:

1. that the words complained of were published;

Martin George, “Hartley on the Problem of 'Libel Tourism'” (19 July 2010), online: Conflict of Laws.net <http://conflict oflaws.net/2010/hartley-on-the-problem-of-libel-tourism/>.

Club Resorts Ltd v Van Breda, 2012 SCC 17, [2012] 1 SCR 572 at para 66 [Club Resorts]. See also Hessel E Yntema, “The Objectives of Private International Law” (1957) 35:6 Can Bar Rev 721.

Defamation covers both slander and libel. However in the case of the Internet, only libel is of interest. See generally Roger D McConchie \& David A Potts, Canadian Libel and Slander Actions (Toronto: Irwin Law, 2004); Allen M Linden \& Bruce Feldthusen, Canadian Tort Law, 8th ed (Markham: LexisNexis, 2006) at 759-815. Note that libel may be the subject of a criminal prosecution, Criminal Code, RSC 1985, c C-46, s 298.

$7 \quad$ Matthew Collins, The Law of Defamation and the Internet (Oxford: Oxford University Press, 2001) at 10. Defamation legislation of the provinces and territories modifies the common law: Defamation Act, RSA 2000, с D-7; Libel and Slander Act, RSBC 1996, с 263; Defamation Act, CCSM, c D-20; Defamation Act, RSNB 2011, c 139; Defamation Act, RSNL 1990, c D-3; Defamation Act, RSNWT 1988, c D-1; Defamation Act, RSNS 1989, c 122; Libel and Slander Act, RSO 1990, c L.12; Defamation Act, RSPEI 1988, c D-5; Libel and Slander Act, RSS 1978, c L-14; Defamation Act, RSY 2002, c 52. David A Potts, Cyberlibel: Information Warfare in the 21st Century? (Toronto: Irwin Law, 2011) at 101. 
2. that the words complained of refer to the plaintiff; and

3. that the words complained of, in their natural and ordinary meaning, or in some pleaded extended meaning, are defamatory of the plaintiff. ${ }^{9}$

In civil law Quebec, although the law of defamation has been influenced by the common law, the Civil Code does not provide a specific statutory cause of action for defamation, nor is there a distinction between slander and libel. Instead, such a cause of action is governed by the general fault-based rules of civil liability. ${ }^{10}$ Any proven injury to the reputation of a person whether verbal or written requires reparation. Nevertheless, the plaintiff must still prove the same three elements set out above. ${ }^{11}$

\section{B. Place of Publication as Place of Tort}

In common law Canada, the concept of publication is closely tied to the concept of the place of tort, which, for choice of law purposes, has been defined by the Supreme Court of Canada as the place where the wrongful activity occurred as that place may play an important role for the determination of the jurisdiction of courts and the choice of the applicable law. ${ }^{12}$ To prove publication the plaintiff must show that the defendant has acted to communicate the defamatory statement to "at least one person other than the plaintiff." 13 The tort of defamation only crystallizes whenever, and wherever, the statement is heard, read, or downloaded by a third party. ${ }^{14}$ As in the United Kingdom ${ }^{15}$ and Australia, ${ }^{16}$ this is the place of tort rather than the place where the defamatory material was composed, posted on the Internet, ${ }^{17}$ or stored, or where the damage to the plaintiff's reputation occurred, which is generally where he or she resides or works. ${ }^{18}$

In the case of defamatory material that is not posted on the Internet, such as newspaper articles, there exists a statutory presumption of publication once a printed copy of the newspaper can be produced. ${ }^{19}$ However, as Justice Abella noted in Crookes, in the case of

Dow Jones, supra note 16.

19 For example in British Columbia see sections 2 and 12(2) of the Libel and Slander Act, RSBC 1996, c 263.

Ibid. See also Leenen v Canadian Broadcasting Corp. (2000), 48 OR (3d) 656 at paras 40-41.

Article 1457 CCQ. Jean-Louis Baudouin \& Patrice Deslauriers, La responsabilité civile: principes généraux, vol 1, 7th ed (Cowansville: Yvon Blais, 2007) at paras 1-291-309, especially 1-291. See also An Act to Establish a Legal Framework for Information Technology, RSQ c C-1.1, s 22 (retention of documents), which discusses the responsibility of the service provider acting as intermediary to provide document storage services on a communication network or to provide technology based documentary refrral services). Section 27 (consultation of documents) states that the service provider is not required to monitor the information communicated on the network or contained in the documents or to identify circumstances indicating that the documents are used for illicit purposes.

Baudouin \& Deslauriers, ibid at para 1-292.

Tolofson v Jensen; Lucas v Gagnon, [1994] 3 SCR 1022 [Tolofson].

Grant v Torstar Corp, 2009 SCC 61, [2009] 3 SCR 640 at para 28. See also Potts, supra note 8 at 227.

Editions Ecosociété Inc v Banro Corp, 2012 SCC 18, [2012] 1 SCR 636 at para 34 [Editions].

Collins, supra note 7 at 69,75 . This is the case outside Scotland where communication only to the defamed person is sufficient.

Dow Jones \& Co Inc v Gutnick, [2002] HCA 56210 CLR 575 at paras 25-27 [Dow Jones].

To avoid the consequences of the place of tort being defined as the place of posting on the Internet, it has been suggested that in the case of multistate publication of a defamatory statement, each statement would be considered as a single publication at the place of posting, whose law would then be applicable to all of them. 
material posted on the Internet, there is no presumption of publication. ${ }^{20}$ As such, "pleadings in defamation actions concerning material posted on the internet require an allegation that the allegedly defamatory posting was communicated to a third person" ${ }^{21}$ in the forum. Thus, the issue of publication is one of proof through affidavits. ${ }^{22}$ To meet this evidentiary burden, the plaintiff has only to establish "a good arguable case" that the material was in fact heard, read, or downloaded by a third party. ${ }^{23}$ To do so, the plaintiff will prove "facts from which it can reasonably be inferred that the words were brought to the knowledge of some third person."24

Based on this short review, it is submitted that the place of hearing, reading, or downloading by a third party is the best approach for determining the place of tort as most often this is where the plaintiff suffers injury to his or her reputation. It is simply not credible to argue that alleged defamers are unable to foresee that the material they post on the Internet has the potential to harm individuals around the globe. This approach also best ensures predictability of legal consequences for both potential plaintiffs and defendants.

\section{JURISDICTION}

Due to the fact that material posted on the Internet can be linked to a variety of people located in different jurisdictions, a claim for Internet defamation raises the important issue of which court can take jurisdiction. This question is crucial as an Internet defamation action brought in one jurisdiction can be decided differently than one brought in another due to things such as the law applicable to the claim which determines what defenses will be available to the defendant.

In Club Resorts, a case which involved claims in tort arising from catastrophic injuries suffered by Canadians while vacationing in Cuba, the Supreme Court of Canada was

Crookes, supra note 1 at para 14. This is also the case in the United Kingdom (Potts, supra note 8 at 240). Furthermore Justice Abella in Crookes, at para 25, held that there is no presumption of publication for hyperlinks. If someone is sued for the inclusion of hyperlinks to a defamatory expression, the plaintiff must prove that the hyperlinks were actually accessed by a third party. More importantly she found that "individuals may attract liability for hyperlinking if the manner in which they have referred to content conveys defamatory meaning; not because they have created a reference, but because, understood in context, they have actually expressed something defamatory" (Crookes, ibid at para 40 [emphasis in original]). Thus someone who publishes hyperlinks on their site will generally not be found liable unless they endorsed the defamatory statement or embedded the hyperlinks such that the link opens to the target website automatically, without activation by the reader. See also Laforest c Collins, 2012 QCCS 3078, [2012] JQ no 6417 (QL). For a summary of the principles of law about publication and hyperlinks see Potts, supra note 8 at 260-61.

$21 \quad$ Nazerali $v$ Mitchell, 2012 BCSC 205, 211 ACWS (3d) 489 at para 19 [Nazerali]. See also Elfarnawani v International Olympic Committee, 2011 ONSC 6784, [2013] AWLD 1288 at para 34 [Elfarnawani]. Elfarnawani, ibid at paras 33-34.

$23 \quad$ Nazerali, supra, note 21 at para 26. See also Court v Debaie, 2012 ABQB 640, 20 CPC (7th) 412 at para 27 [Court] and Editions, supra note 14 at para 38. In Braintech v Kostiuk (1999), 171 DLR (4th) 46 (BCCA), passive posting of alleged defamatory material on an Internet bulletin board did not in itself constitute a tort in Texas where it was accessible in the absence of evidence that someone read it.

Nazerali, ibid at para 25. In this case, the plaintiff was able to present to the Court three affidavits in order to meet this evidentiary burden, yet the Court observed that none of the deponents asserted that they actually read the allegedly defamatory statements. Nevertheless, the Court concluded that the affidavits, combined with the notice of civil claim, provided a sufficient basis for the Court to infer that the defamatory statements were published in the forum. The Court reasoned that although none of the deponents asserted that they read the allegedly defamatory statements, the substance of the depositions reflected the derogatory meanings alleged in the notice of civil claim. See also Crookes v Yahoo, 2007 BCSC 1325, 75 BCLR (4th) 316 at para 30; Court, supra note 23 at paras 29-34 (where it was held that in Alberta even hearsay evidence could be relied upon). 
concerned with "the elaboration of the 'real and substantial connection test' as an appropriate common law conflicts rule for the assumption of jurisdiction" also called jurisdiction simpliciter. ${ }^{25}$ It was not concerned with "the constitutional test for adjudicative jurisdiction for a case in which a conflicts rule is challenged on the basis of inconsistency with constitutionally imposed territorial limits. ${ }^{26}$ In finding that the Ontario court could assume jurisdiction as it had a real and substantial connection with the subject matter of the litigation and the defendants, the Supreme Court refined the test by holding that the preferred approach in Canada should be to rely on a set of specific factors which are given presumptive effect in order to ensure security and predictability in the law governing the assumption of jurisdiction by Canadian courts. The values of order, certainty, and comity must form the basis of the system to permit the development of a just and fair approach to resolving conflicts of jurisdiction. In other words, a proper balance must be struck between flexibility, certainty, and predictability. ${ }^{27}$

In the case of torts, the court identified the following presumptive connective factors that link the subject of the litigation and the forum:

(a) the defendant is domiciled or resident in the province;

(b) the defendant carries on business in the province;

(c) the tort was committed in the province; and

(d) a contract connected with the dispute was made in the province. ${ }^{28}$

The party arguing that the court should assume jurisdiction has the burden of identifying these presumptive connecting factors. The presumption of jurisdiction is not irrebuttable. The burden of rebutting the presumption rests on the party challenging the assumption of jurisdiction. Over time this list of presumptive connecting factors may be reviewed and updated. "In identifying new presumptive factors, a court should look to connections that give rise to a relationship with the forum that is similar in nature to the ones which result from the listed factors." 29

With respect to the commission of the tort in the province which is listed in (c) as an appropriate presumptive connecting factor that prima facie entitles the court of that place to assume jurisdiction over the dispute, the Supreme Court pointed out that "the difficulty lies in locating its situs, not in acknowledging [its] validity." 30 This connecting factor is recognized by rule 17.02(g) of the Ontario Rules of Civil Procedure ${ }^{31}$ and section 10(g) of

Club Resorts, supra note 5 at para 34.

Ibid.

Ibid at para 73

Ibid at para 90.

Ibid at paras 91-92. See also Frank v Farlie, Turner \& Co, 2012 ONSC 5519, 113 OR (3d) 25 at paras 109-29, especially 113-14.

Ibid at para 88.

RRO 1990, Reg 194. Service outside Ontario without leave with respect to claims based on a tort committed in Ontario. 
the Uniform Court Jurisdiction Proceedings Transfer Act. ${ }^{32}$ The Supreme Court also remarked that determining the situs of the tort of defamation by resorting to the use of damage sustained as a connecting factor should not raise difficult issues since "sustaining damage completes the commission of the tort and often tends to locate the tort in the jurisdiction where the damage is sustained." 33

In Breeden v. Black, Justice Lebel had the opportunity to apply the presumptive connecting factors which he listed in Club Resorts to the case of six multistate libel actions regarding material posted on the Internet by defendants located outside Canada. ${ }^{34}$ He held that: "The issue of assumption of jurisdiction is easily resolved in this case based on a presumptive connecting factor - the alleged commission of the tort of defamation in Ontario." ${ }^{35}$ He also noted that: "It is well established in Canadian law that the tort of defamation occurs upon publication of a defamatory statement to a third party" and in the case at bar there was evidence that at least one third party had read, downloaded, and republished the defamatory material in Ontario. ${ }^{36}$ The defendants had argued that in situations involving multistate libel claims, the "place of reading" approach should be abandoned in favour of one "that considers whether a real and substantial connection exists between the forum and the substance of the action";37 "[i]n the case of a libel claim, that is the subject matter and conduct giving rise to the words complained of and the context in which they were made." ${ }^{38}$ In this case, since the substance of Lord Black's activities was American, both New York and Illinois were more appropriate forums. They also argued that a focus on the damage sustained in the jurisdiction should be rejected. ${ }^{39}$ In Editions Ecosociété Inc., which was also released at the same time, Justice Lebel came to a similar conclusion as in Breeden that the alleged tort of defamation occurred in Ontario where the book containing the alleged libelous material was distributed and available for purchase on the publisher's website. ${ }^{40}$ The defendants had argued that in multistate defamation cases there must at least be substantial publication for a court to find a real and substantial connection. ${ }^{41}$ They had also argued that there was no evidence on the record that suggested that the plaintiff suffered harm to his reputation in Ontario. ${ }^{42}$

Although it would appear from these two leading cases that the law in common law Canada has settled upon the place of publication as representing the place of tort for defamation, things are not so black and white. In Editions, when determining whether the

Uniform Law Conference of Canada, Uniform Court Jurisdiction and Proceedings Transfer Act (1996), online: <http://www.ulcc.ca/en/uniform-acts-en-gb-1/183-court-jurisdiction-and-proceedings-transferact/1092-court-jurisdiction-proceedings-transfer-act?showall-1\&limitstart $=>$. See e.g. Court Jurisdiction and Proceedings Transfer Act, SBC 2008, c 28, s 10(g). A real and substantial connection is presumed to exist if the proceeding concerns a tort committed in British Columbia.

Club Resorts, supra note 5 at para 89.

Breeden v Black, 2012 SCC 19, [2012] 1 SCR 666 [Breeden SCC].

Ibid at para 20.

Ibid.

Ibid at para 15

Ibid.

Ibid at para 16 .

Editions, supra note 14 at para 38: "At this stage of the proceedings, the plaintiff need not show evidence of harm or that the book was read. The plaintiff need only allege publication and its allegations should be accepted as pleaded unless contradicted by evidence adduced by the defendants.” Ibid at para 22. Actually, 15 copies of the book were circulated in Ontario libraries but only one copy was checked out. Ibid at para 38.

Ibid at para 23 . 
forum had jurisdiction simpliciter, Justice Lebel still stressed the fact that the plaintiff had adduced evidence establishing that its reputation was vital to it in the forum state. ${ }^{43}$ Thus, the importance of the plaintiff's reputation seems also to be a reason why the place of publication as the place of tort was favoured since it was there that the plaintiff suffered harm to his reputation. However, it should not be relevant to establish jurisdiction. To inject this type of a consideration at the jurisdiction simpliciter stage would subject the plaintiff to a problematic evidentiary burden that does not exist in domestic cases.

In civil law Quebec, the place of tort as the place of publication does not play such a significant role in establishing jurisdiction in defamation cases since, according to article 3148 of the Civil Code, a Quebec authority may take jurisdiction where "(3) a fault was committed in Québec, damage was suffered in Québec, [or] an injurious act occurred in Québec.” Publication in Quebec of the defamatory material would amount to a fault committed in Quebec. It would also be an injurious act. These bases for the exercise of jurisdiction in defamation cases would meet the test of jurisdiction simpliciter, ${ }^{44}$ even with respect to the use of "damage suffered in Québec" which completes the commission of the defamation.

The European Union has adopted an even more flexible approach to jurisdiction. ${ }^{45}$ In the joined cases of eDate and Martinez, the European Court of Justice (ECJ) interpreted article 5(3) of the Brussels I Regulation regarding jurisdiction in the case of multistate Internet defamation. ${ }^{46}$ This article stipulates that the court of the forum in which the "harmful event" occurred has jurisdiction. This term has been interpreted to include both the place where the defamatory material has been read, heard, or seen or where the publisher was established. ${ }^{47}$ Furthermore, in eDate and Martinez the ECJ ruled that a plaintiff may bring an action in one forum in respect of all damage caused in the European Union and that forum could also be where the alleged victim has his "centre of interests.",48

Although some scholars have criticized this trend of flexibility as promoting "libel tourism," the Club Resorts framework for the assumption of jurisdiction, it must be remembered that where a recognized connecting factor applies, it is not irrebutable. The defendant can try to establish facts that demonstrate that the presumptive connecting factor does not point to any real relationship between the subject matter of the litigation and the forum. ${ }^{50}$ For example,

Ibid at para 38

Spar Aerospace Ltd v American Mobile Satellite Corp, 2002 SCC 78, [2002] 4 SCR 205. In this case, for the purpose of establishing jurisdiction pursuant to article 3148(3) of the Civil Code of Québec, a claim for a nominal sum for loss of reputation was held to have been suffered in Quebec where most of the respondent's operations took place and not at its corporate head office in Ontario. See also Centre de coopération internationale en santé et developpement c Aide à l'enfance Canada/Save the Children Canada, 2006 QCCS 911, [2006] JQ no 1458 (QL).

45 Worldwide, there is a growing trend of national courts exercising jurisdiction over foreign publishers and individuals (Collins, supra note 7 at 283, 286, 289). 161/10, [2011] ECR 00000 [eDate and Martinez].

161/10, [2011] ECR 00000 [
Collins, supra note 7 at 490 .

48

Supra note 46 at para 48 . See also Collins, ibid. This concept of "centre of interests" is useful in order to determine where the plaintiff has the most significant reputation to protect for the purpose of choice of law.

$49 \quad$ George, supra note 4.

$50 \quad$ Club Resorts, supra note 5 at para 96. 
in the case of a multistate defamation claim involving the Internet, the defendant could attempt to convince the court that he or she has limited the access to the allegedly defamatory material. $^{51}$

In addition, "the [Club Resorts] test for assuming jurisdiction does not turn upon a comparison with the strength of the connection with another potentially available jurisdiction." ${ }^{2}$ Yet, even if jurisdiction simpliciter is established, this jurisdiction can be declined on the basis that there is a clearly more convenient forum for the determination of the dispute between the parties. ${ }^{53}$ This safety valve can be understood to represent a potent weapon in the fight against libel tourism as it ensures that the most appropriate forum will hear the case. Nevertheless, Justice Lebel's judgment in Breeden demonstrates that, in cases of multistate Internet defamation, this doctrine may be less potent than it appears. When Justice Lebel applied the forum non conveniens analysis he found that both the courts of Illinois and Ontario were appropriate forums for the trial of the libel actions. ${ }^{54}$ Although many factors weighed in favour of the Illinois court, Justice Lebel did not declare it to be a clearly more appropriate forum as he believed that the weight of the alleged harm to the plaintiff's reputation tipped the balance in favour of the forum. ${ }^{55}$ Nevertheless, it is suggested that the most potent weapon in the fight against libel tourism is a proper choice of law rule. This is because it is the substantive law applicable to the claims that will ultimately determine their outcome and the available defenses.

\section{CHOICE OF LAW}

Fairness to the plaintiff in the sense of easy access to the courts is justified in the case of jurisdiction simpliciter, yet there should be a clear distinction between jurisdiction and choice of law rules. ${ }^{56}$ Jean-Gabriel Castel explains that "rules of jurisdiction and of choice of law address different concerns and that the test of place of publication should not always be used for both purposes." 57 If fairness dictates that the plaintiff should be able to choose the courts where publication took place, the choice of jurisdiction should not automatically warrant the application of the law of that forum. ${ }^{58}$ This would encourage forum shopping. Instead it is contended that choice of law rules should, first and foremost, reflect the most characteristic element of the tort of defamation, which is the protection of reputation. ${ }^{59}$ Thus, choice of law rules should focus squarely on the law of the place where the reputation of the plaintiff has been most injured. Nevertheless, this focus should be balanced with considerations of fairness to the defendant in the sense of the defenses which are available to him or her. Does Canada's approach to choice of law apply these principles?

For an example of a case where this argument was accepted see Bangoura $v$ Washington Post (2005), 258 DLR (4th) 341 (Ont CA).

Black v Breeden, 2010 ONCA 547, 102 OR (3d) 748 at para 48.

For a description of the forum non conveniens analysis see Breeden SCC, supra note 34 at paras 22-28; Club Resorts, supra note 5 at paras 101-13.

Breeden SCC, ibid at para 29. In Quebec see article 3135 of the Civil Code of Québec to the same effect. Breeden SCC, ibid at para 38.

It has been observed that the distinction between choice-of-law and jurisdictional rules for defamation claims is often murky (Warshaw, supra note 1 at 274).

J-G Castel, "Multistate Defamation: Should the Place of Publication Rule Be Abandoned for Jurisdiction and Choice of Law Purposes?" (1990) 28:1 Osgoode Hall LJ 153 at 163 [Castel, "Multistate Defamation"]. Also cited by the Supreme Court of Canada in Editions, supra note 14 at paras 60-61. Castel, "Multistate Defamation,” ibid. Ibid. 
With respect to torts, the choice of law rule in common law Canada is the lex loci delicti, interpreted as the law of the place where the wrongful act or omission occurred. ${ }^{60}$ This is "because the law of that place must determine the character of the wrong and its legal consequences." ${ }^{61}$ As explained above, in the case of defamation claims, the place of tort is the place where the allegedly defamatory statement was read, heard, or downloaded by a third party.

This formulation seems to adopt the same approach as that used to establish jurisdiction, yet the jurisprudence suggests that the law in this area is not yet settled. In the three recent cases of Editions, ${ }^{62}$ Breeden, ${ }^{63}$ and Court $^{64}$ the courts acknowledged that:

[T] here is some question as to whether the lex loci delecti rule, according to which the applicable law is that of the place where the tort occurred, ought to be abandoned in favour of an approach based on the location of the most harm to reputation. ${ }^{65}$

In Editions, Justice Lebel comprehensively addressed this question ${ }^{66}$ in order to reject the defendants, suggestion that the English approach requiring substantial publication should be adopted, because in Canada a single instance of publication is sufficient for the tort to crystallize. Instead, Justice Lebel explored the possibility that the choice of law rule for cases of defamation should be the law of the place of the most substantial harm to reputation. He noted that this approach was adopted in Australia ${ }^{67}$ and was motivated by concerns that the application of the lex loci delicti rule to such claims would encourage forum shopping. ${ }^{68}$ This observation is accurate, and if Canada wishes to avoid forum shopping and also adequately protect reputation, it should adopt the Australian approach to choice of law and recognize that in defamation claims, the material posted on the Internet may harm an individual's reputation in many places, yet there will only be one place where it will be hurt the most. ${ }^{69}$

$60 \quad$ Tolofson, supra note 12 at 1040.

61 Jean-Gabriel Castel, Canadian Conflict of Laws, 6th ed by Janet Walker (Markham: LexisNexis, 2005) vol 2 at para 35-17 [Castel, Canadian Conflict of Laws].

Editions, supra note 14 at para 56.

Breeden SCC, supra note 34 at para 32.

Court, supra note 23 at para 49.

Breeden SCC, supra note 34 at para 32.

Editions, supra note 14 at paras 56-62.

Ibid at para 59. It should also be noted that choice of law rules for torts in Europe are the subject of the regulation of the European Parliament and the Council of the European Union (EC, Regulation (EC) 864/2007 of the European Parliament and of the Council of 11 July 2007 on the law applicable to noncontractual obligations (Rome II), [2007] OJ, L 199/40). This Regulation stipulates in article 4(1) that the lex loci delicti rule applies to liability claims, yet Article 2(g) expressly excludes defamation from the scope of the Regulation. Nevertheless, the Committee on Legal Affairs of the European Parliament has submitted a new draft report which takes into account the eDate decision cited above (supra note 46) with recommendations to the Commission about a choice of law rule for privacy and personality rights. Recommended is a rule which applies the law "of the country in which the rights of the person seeking compensation for damage are, or are likely to be, directly and substantially affected” (European Parliament, Draft Report with recommendations to the Commission on the amendment of Regulation (EC) No 864/2007 on the law appicable to non-contractual obligations (Rome II) (2009/2170 (INI)) at 8).

68 Editions, ibid at para 60.

69 In order to determine where the plaintiff has the most significant reputation to protect the European concept of his or her "centre of interests" could be of use (supra note 48). This is important where the plaintiff has a significant reputation in more than one country, as in the case of a sports or movie celebrity. 
It is also fair to potential defendants since countries often strike a different balance between protection of reputation and freedom of speech considerations. This is reflected in the domestic law defences available to alleged defamers. The most substantial harm to reputation approach to choice of law respects these domestic choices by allowing a defendant in a multistate Internet defamation claim to have access to the defences available in the jurisdiction where the plaintiff has the most significant reputation to protect. In Breeden, the defendants should have foreseen where their statements would cause the most harm to the plaintiff. The application of the law where the most substantial harm occurred to the plaintiff's reputation does not curtail freedom of speech; it rather ensures the respect of different domestic approaches to it.

Since in common law Canada, the post-Tolofson case law has admitted a number of exceptions to the rigid application of the lex loci delicti as a means of achieving fairness in certain circumstances, ${ }^{70}$ there is no reason the courts could not apply, to cases of defamation on the Internet, the law of the place where the plaintiff suffered the most substantial harm to his or her reputation. This is also the case in civil law Quebec where article 3126 of the Civil Code calls for the application of the lex loci delicti, defined as the law of the country where the injurious act occurred, as the basic rule, but also provides for the application of the law where the damage occurred if the person who committed the injurious act should have foreseen that the damage would occur there. This limited exception to the basic rule could allow Quebec courts to apply the law of the place where the plaintiff suffered the most substantial harm to his or her reputation. ${ }^{71}$

\section{CONCLUSION}

In this review of jurisdiction and choice of law issues in multistate defamation on the Internet, it is suggested that the place of publication interpreted as the place of downloading should be retained as the place of tort, however defined, as there can be multiple places for the tort for other purposes, provided enough of the tort of defamation is connected with the jurisdiction to justify the court taking charge of the case. It is also suggested that in order to establish jurisdiction simpliciter, Canadian common law courts should continue to assume jurisdiction on the basis of the place of tort. This rule would not promote libel tourism as it is kept in check by the doctrine of forum non conveniens and also by a choice of law rule which would apply the law of the place of most substantial harm to the plaintiff's reputation, rather than the law of the place of publication. This choice of law rule maintains a proper balance between the reputational interests of the plaintiff and the freedom of speech concerns of the defendant in addition to respecting comity as the organizing principle of the conflict of laws.

Castel, Canadian Conflict of Laws, supra note 61 at para 35-6.

The French version is the proper one as the English translation is not accurate unless the work "there" is added at the end of the paragraph. Another exception allows for the application of the law of the common domicile or residence of the parties involved (second para of art 3126). See G Goldstein \& E Groffier, Droit international privé, vol II (Cowansville: Yvon Blais, 2003) at paras 466, 479. See also G Goldstein, Commentaries sur le Code civil du Québec Droit International privé, vol 1 (Cowansville: Yvon Blais, 2011) at 646. Note that in Tolofson, supra note 12, Justice La Forest analyzing Machado $v$ Fontes, [1897] 2 QB 231, added parenthetically that unlike a motor accident, "the tort of libel should be held to take place where its effects are felt” (Tolofson, ibid at 1042). This could be the place of most substantial harm. 
As far as Quebec is concerned, articles 3148(3) and 3135 (as interpreted by Spar Aerospace Ltd.) and article 3126 of the Civil Code provide a flexible solution to actions involving multistate defamation on the Internet. 